and the fourth elution with 2 liter of $\mathrm{CHCl}_{3}$ gave respectively $0.47 \mathrm{~g}, 1.20 \mathrm{~g}$, and $1.07 \mathrm{~g}$ of pale yellow semisolids (II). IR $v_{\mathrm{max}}^{\mathrm{CHCl}_{3}} \mathrm{~cm}^{-1}: 1615,1550$ and 1500 . NMR in $\mathrm{CDCl}_{3}(\tau): 5.15$ (-CO-CH=C<). Picrate, mp $175-177^{\circ}$ (decomp.) (from iso-PrOH). Anal. Calcd. for $\mathrm{C}_{19} \mathrm{H}_{22} \mathrm{O}_{8} \mathrm{~N}_{4}: \mathrm{C}, 52.53 ; \mathrm{H}, 5.10 ; \mathrm{N}, 12.90$. Found: C, $52.26 ; \mathrm{H}, 5.05 ; \mathrm{N}, 12.89$. The total yield of II was $2.74 \mathrm{~g}(30 \%)$.

The fifth elution with 1.4 liter of $\mathrm{CHCl}_{3}-\mathrm{EtOH}(20: 1)$ and the sixth elution with $\mathrm{EtOH}(500 \mathrm{ml})$ gave respectively $0.99 \mathrm{~g}$ and $0.48 \mathrm{~g}$ of a brown semi-solid (III). IR $v_{\max }^{\mathrm{CHCl}_{2}} \mathrm{~cm}^{-1}: 1640$ (sh), 1625, 1560 , and 1525 . NMR in $\mathrm{CDCl}_{3}(\tau): 3.85(-\mathrm{CO}-\mathrm{CH}=\mathrm{C}<, 1 \mathrm{H}$, singlet). Picrate, yellow needles from EtOH-acetone, mp 225$228^{\circ}$ (decomp.). Anal. Calcd. for $\mathrm{C}_{19} \mathrm{H}_{20} \mathrm{O}_{8} \mathrm{~N}_{4}: \mathrm{C}, 52.78 ; \mathrm{H}, 4.66 ; \mathrm{N}, 12.96$. Found: C, 52.65; $\mathrm{H}, 4.79$; $\mathrm{N}, 12.65$. The total yield of III was $1.57 \mathrm{~g}(16 \%)$.

4a-Methyldodecahydro- $6 \boldsymbol{H}$-benzo[c]quinolizin-6-one (IV)_- To the Grignard reagent prepared from $\mathrm{Mg}$ $(219 \mathrm{mg}, 9.0$ matoms $), \mathrm{CH}_{3} \mathrm{I}(1.28 \mathrm{~g}, 9.0 \mathrm{mmoles})$ and anhydrous ether $(20 \mathrm{ml})$ was added $\mathrm{Cu}_{2} \mathrm{Br}_{2}(140 \mathrm{mg}$, $0.97 \mathrm{mmole}$ ) in one portion. A solution of the compound (II) (370 $\mathrm{mg}, 1.8 \mathrm{mmoles}$ ) in anhydrous ether $(20 \mathrm{mI})$ was added dropwise to the above mixture at R.T. and then refluxed with stirring for $1.5 \mathrm{hr}$. The reaction mixture was decomposed with aq. saturated $\mathrm{NH}_{4} \mathrm{Cl}$ solution under ice-cooling. The ethereal layer was separated and the aq. layer was shaken with ether $(30 \mathrm{ml} \times 4)$. The combined ether extracts were washed with brine and dried over anhydrous $\mathrm{K}_{2} \mathrm{CO}_{3}$. Evaporation of ether gave a brown oil (300 $\left.\mathrm{mg}\right)$, which was chromatographed on alumina $(15 \mathrm{~g})$. The first elution with $300 \mathrm{ml}$ of benzene gave a pale yellow oil (IV) $(80 \mathrm{mg}, 21 \%)$. IR $v_{\max }^{\mathrm{CHCl}_{3}} \mathrm{~cm}^{-1}: 2800,2755$ and 1710. NMR in $\mathrm{CDCl}_{3}(\tau): 9.05\left(3 \mathrm{H}\right.$, singlet, $\left.>\mathrm{C}-\mathrm{CH}_{3}\right)$. Picrate, yellow needles from acetone, mp 219-220 (decomp.). Anal. Calcd. for $\mathrm{C}_{20} \mathrm{H}_{26} \mathrm{O}_{8} \mathrm{~N}_{4}: \mathrm{C}, 53.33$; $\mathrm{H}, 5.82 ; \mathrm{N}, 12.44$. Found: $\mathrm{C}, 53.19 ; \mathrm{H}, 5.70 ; \mathrm{N}, 12.51$.

The second elution. with $500 \mathrm{ml}$ of $\mathrm{CHCl}_{3}$ gave the starting material $(200 \mathrm{mg}, 54 \%)$. IR $v_{\mathrm{max}}^{\mathrm{CHCl}_{3}} \mathrm{~cm}^{-1}$ : 1615 and 1550.

5-Acetyl-1,2,3,4,6a,7,8,9,10,10a-decahydro-6H-benzo[c]-quinolizin-6-one $(\mathrm{V})$ - $\mathrm{A}$ solution of the compound (II) $(560 \mathrm{mg})$ in $\mathrm{Ac}_{2} \mathrm{O}(10 \mathrm{ml})$ in the presence of $\mathrm{BF}_{3} \cdot$ ether $(2.5 \mathrm{ml})$ was refluxed for $1.5 \mathrm{hr}$. After cooling, the reaction mixture was poured into ice-water, basified with $20 \% \mathrm{NaOH}$ and shaken with $\mathrm{CHCl}_{3}$ $(50 \mathrm{ml} \times 5)$. The combined extracts were washed with $\mathrm{H}_{2} \mathrm{O}$ and dried over anhydrous $\mathrm{K}_{2} \mathrm{CO}_{3}$. Evaporation of $\mathrm{CHCl}_{3}$ afforded a dark brown solid $(570 \mathrm{mg})$, which was chromatographed on alumina (30 g). The first elution with $300 \mathrm{ml}$ of benzene gave the starting material $(70 \mathrm{mg}, 13 \%)$. IR $v_{\max }^{\mathrm{CrCl}_{8}} \mathrm{~cm}^{-1}: 1615$ and 1550 .

The second elution with $200 \mathrm{ml}$ of benzene- $\mathrm{CHCl}_{3}(1: 1)$, and the third elution with $350 \mathrm{ml}$ of $\mathrm{CHCl}_{3}$ gave respectively $45 \mathrm{mg}$ and $315 \mathrm{mg}$ of a pale pink colored solid (V), which was recrystallized from $n$-hexanebenzene $(4: 1)$ to give pink colorled needles, mp $119-120^{\circ}$ (decomp.). Anal. Calcd. for $\mathrm{C}_{15} \mathrm{H}_{21} \mathrm{O}_{2} \mathrm{~N}: \mathrm{C}, 72.84$;

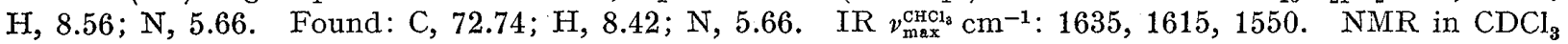
$(\tau): 7.55\left(3 \mathrm{H}\right.$, singlet, $\left.\geq \mathrm{C}-\mathrm{CO}-\mathrm{CH}_{3}\right)$. The total yield of $\mathrm{V}$ was $360 \mathrm{mg}(54 \%)$.

\title{
Antitumor Activity of Psychotropic Drugs and Their Synergic Action with Cyclophosphamide
}

\author{
Akio Hoshi, Fuminiko Kanzawa, \\ and Kazuo Kuretani \\ Pharmacology Division, National Cancer Center Research Institute1)
}

(Received November 1, 1968)

It has been reported that chlorpromazine has weak antitumor activity on Walker $256^{2}$ ) and Sarcoma $37,{ }^{3,4)}$ and also some other phenothiazine derivatives have the same effect on

1) Location: Tsukiji 5-chome, Chuo-ku, Tokyo.

2) F. Paulesu and L. Vargiu, Georn. Ital. Chemiother., 2, 70 (1955).

3) M. Belkin and W.G. Hardy, Science, 125, 233 (1957).

4) E. Hirschberg, Cancer Res., suppl., 23, 521 (1963). 
Sarcoma $180^{5)}$ and Walker 256.,.$^{2,4)}$ Moreover, chlorpromazine ${ }^{6)}$ and imipramine ${ }^{7)}$ have been found to enhance the activity of cyclophosphamide.

The purpose of the present studies is to investigate the possible synergistic antitumor activity of chlorpromazine and other psychotropic drugs with cyclophosphamide.

\section{Experimental}

\section{Materials and Methods}

Female mice of ddN strain weighing $20 \pm 2 \mathrm{~g}$ and Sarcoma 180 ascites tumor were used. The procedure is as follows: Each mouse, twelve animals in each group, was transplanted intraperitoneally $3 \times 10^{2}$ tumor cells, and was injected the drug to be tested intraperitoneally, one-third dose of each $\mathrm{LD}_{50}$, once daily for 5 days, starting 6 hours after implantation. For the combination therapy, $20 \mathrm{mg} / \mathrm{kg} / \mathrm{day}$ of cyclophosphamide, corresponding to $\mathrm{ED}_{20}$, was injected intraperitoneally once daily for 5 days, starting 24 hours after implantation, while the drug to be tested was injected in the same procedure as above mentioned.

Tumor growth inhibition was evaluated with the total packed cell volume (TPCV) ratio, which was measured at the 8th day after implantation. ${ }^{8)}$ Ascites volume was measured in graduated cylinder, and ascitocrit was determined in capillary tube in a microhematocrit centrifuge. TPCV was calculated simply as the product of above two values. When ascites was nondetectable, it was defined as "regression," and the regression ratio was expressed by the number of regressed animals per total survivors at that day.

The following thirteen psychotropic drugs, mainly phenothiazine derivatives, were used: chlorpromazine, promethazine, and prochlorperazine (Shionogi Co., Ltd.), chlorprothixene and methotrimeprazine (Yoshitomi Pharmaceutical Ind., Ltd.), imipramine, desmethylimipramine, and opipramol (Fujisawa Pharmaceutical Co., Ltd.), amitriptyline (Nippon Shinyaku Co., Ltd.), promazine (Banyu Pharmaceutical Co., Ltd.), meprobamate (Daiichi Seiyaku Co., Ltd.), and pentobarbital (Tanabe Seiyaku Co., Ltd.).

\section{Results and Discussion}

As shown in Table I, chlorpromazine was found to be weakly active on Sarcoma 180 ascites tumor in inhibiting its growth. Chlorprothixene and methotrimeprazine were more active than chlorpromazine, and the tumor regression was also observed in over a half of the animals. Desmethylimipramine and prochlorperazine inhibited the tumor growth. Promazine, opipramol, amitriptyline, imipramine, and prothipendyl were weakly active almost equal to chlorpromazine. Promethazine, meprobamate and pentobarbital were inactive.

As a result, some of the phenothiazine and iminodibenzyl derivatives were found to have stronger activity than chlorpromazine.

Mechanism of action of these drugs on the tumor was not clear, and their potencies did not correlate to their pharmacological activities such as tranquilizing and antidepressing activities.

Tumor growth was inhibited slightly (about 20\%) with low dose of cyclophosphamide $\left(20 \mathrm{mg} / \mathrm{kg} /\right.$ day $\times 5$ days). When one-third of $\mathrm{LD}_{50}$ of psychotropic drug was combined with cyclophosphamide, sometimes, not only tumor growth inhibition was increased, but also tumor regression was increased. Such effect was produced by the following four drugs: desmethylimipramine, prochlorperazine, chlorpromazine, and imipramine. Also, almost of other drugs enhanced tumor growth inhibition but regression was not so affected. Tumor growth inhibiting activity of cyclophosphamide was not depressed with any of the psychotropic drugs tested.

The enhancement of antitumor activity, including growth inhibition and regression, of cyclophosphamide in combination of psychotropic drugs was supposed not to be the simple

5) K. Sugiura, Ann. N.Y. Acad. Sci., 76, 575 (1958).

6) I.K. Cohen and C.G. Thomas, Jr., Proc. Amer. Ass. Cancer Res., 4, 11 (1963).

7) A. Hoshi, F. Kanzawa, K. Kumagai, and K. Kuretani, the 26th Annual Meeting of Japanese Cancer Association, Nagoya, Oct. 1967.

8) E.N. Sassenrath, Ann. N.Y.Acad. Sci., 76, 601 (1958). 
Table I. Antitumor Activity of the Psychotropic Drugs and Their Combination Effect of Cyclophosphamide plus One-third of $\mathrm{LD}_{50}$ of the Drugs

\begin{tabular}{lccccc}
\hline \hline \multicolumn{1}{c}{ Drug } & $\begin{array}{c}\text { Dose } \\
(\mathrm{mg} / \mathrm{kg} / \mathrm{day})\end{array}$ & $\begin{array}{c}\text { Inhibition in TPCV } \\
\text { Drug alone }\end{array}$ & $\begin{array}{c}\text { Regression ratio } \\
\text { Combination }\end{array}$ & $\begin{array}{c}\text { Drug alone Combination } \\
\text { Drumer }\end{array}$ \\
\hline Chloroprothixene & 25.0 & ++ & +++ & $8 / 12$ & $9 / 12$ \\
Desmethylimipramine & 45.0 & ++ & +++ & $3 / 9[3]$ & $7 / 8^{c)}[4]$ \\
Methotrimeprazine & 25.0 & ++ & +++ & $7 / 11[1]$ & $6 / 10[2]$ \\
Prochlorperazine & 50.0 & ++ & +++ & $2 / 12$ & $10 / 11^{d)}$ \\
Promazine & 40.0 & ++ & ++ & $3 / 12$ & $6 / 12$ \\
Opipramol & 50.0 & + & ++ & $2 / 12$ & $5 / 12$ \\
Amitriptyline & 30.0 & + & + & $2 / 11$ & $2 / 12$ \\
Prothipendyl & 50.0 & + & + & $0 / 11$ & $2 / 11$ \\
Chlorpromazine & 25.0 & + & ++ & $1 / 10$ & $7 / 12^{c)}$ \\
Imipramine & 40.0 & + & ++ & $1 / 11$ & $6 / 11^{c)}$ \\
Pentobarbital & 40.0 & - & - & $0 / 10$ & $0 / 12$ \\
Promethazine & 25.0 & - & + & $1 / 12$ & $2 / 12$ \\
Meprobamate & 100 & - & - & $1 / 11$ & $0 / 11$ \\
Cyclophosphamide & 20.0 & - & & $0 / 12$ & \\
\hline
\end{tabular}
a) $-34 \%$ or less in inhibition $(P>0.05),+: 35-59 \%(P<0.05),++: 60-89 \%(P<0.01)$,
$+++: 90 \%$ or more $(P<0.001)$

$b$ ) Evaluated at the 8 th day after implantation.

c) Effect of combination treatment was greater than that of drug alone $(P<0.05)$.

d) Effect of combination treatment was greater than that of drug alone $(P<0.01)$.

[ N Number of animals died from drug toxicity.

addition of antitumor activity, but rather to be due to other effects of drugs such as modification of cell membrane permeability, as reported previously in the case of imipramine.9)

In conclusion, some of the derivatives of phenothiazine and iminodibenzyl were found to be especially active in tumor growth inhibition and regression in combination with cyclophosphamide.

Acknowledgement The authors are grateful to Fujisawa Pharmaceutical Co., Ltd. for gifts of imipramine and opipramol and to Banyu Pharmaceutical Co., Ltd. for promazine.

9) A. Hoshi, F. Kanzawa, and K. Kuretani, the 88th Annual Meeting of Pharmaceutical Society of Japan, Tokyo, Apr. 1968. 